\title{
HYDROTHERMAL TREATMENT OF EUCALYPTUS STRAND PARTICLES FOR IMPROVEMENT OF ORIENTED STRAND BOARD (OSB)
}

\author{
Carvalho $\mathrm{AG}^{1}$, Zanuncio $\mathrm{AJV}^{1,}$ *, Carneiro $\mathrm{ACO}^{2}$, da Silva $\mathrm{CMS}^{2}$, Erkel EG $\mathrm{EG}^{3}$. Vital $\mathrm{BR}^{2}$ \\ ${ }^{1}$ Universidade Federal de Uberlândia, Instituto de Ciências Agrárias. Monte Carmelo, Minas Gerais state, 38500-500 Brazil \\ ${ }^{2}$ Universidade Federal de Viçosa, Departamento de Engenharia Florestal, Viçosa, Minas Gerais state, 36570-900 Brazil \\ ${ }^{3}$ Universiadade Estadual do Centro-Oeste, Departamento de Engenharia Florestal, Irati, Paraná State, 84500-000 Brazil \\ *ajvzanuncio@ufu.br
}

Submitted April 2019, accepted November 2019

\begin{abstract}
The aim of this study was to evaluate the effect of hydrothermal treatment on the chemical composition of Eucalyptus strand particles and on the physical and mechanical properties of oriented strand board (OSB) panels. Strand particles of Eucalyptus were pre-hydrolysed at 130, 150 and $170{ }^{\circ} \mathrm{C}$ for 7 and 21 minutes. The extractives, lignin, carbohydrates, $\mathrm{pH}$, equilibrium moisture content, mass loss and contact angle were evaluated. The OSB panels were fabricated using a phenol-formaldehyde adhesive (8\%), $0.7 \mathrm{~g} \mathrm{~cm}^{-3} \mathrm{nominal}$ density and a pressing cycle with $170{ }^{\circ} \mathrm{C}, 3.14 \mathrm{MPa}$ for 8 minutes. These panels were kept in a climate chamber at $20 \pm 2{ }^{\circ} \mathrm{C}$ and $65 \pm 3 \%$ relative humidity to determine their physical and mechanical properties. The hydrothermal treatment, mainly at $170{ }^{\circ} \mathrm{C}$, degraded the hemicelluloses, especially galactans, xylans and arabians. The treatments at this temperature showed the best results for improving the dimensional stability, as well as reducing the moisture equilibrium content, water absorption and thickness swelling after 24 hours of immersion, without losing mechanical resistance. Therefore, hydrothermal treatment can be an important alternative for improving OSB panel quality.
\end{abstract}

Keywords: Dimensional stability, particleboard, physical properties, pre-hydrolysis, wood chemistry

\section{INTRODUCTION}

Oriented strand board (OSB) panels are commercially produced with the genus Pinus, with a wood density ranging from 0.3 to $0.5 \mathrm{~g}$ $\mathrm{cm}^{-3}$ (Mendes et al. 2013a, Sanches et al. 2016, Delucis et al. 2017). Panel production demands timber with up to $0.55 \mathrm{~g} \mathrm{~cm}^{-3}$ density (Moslemi, 1974). Many fast-growing Eucalyptus species with high productivity can also be used to increase the raw material supply and substitute Pinus spp. (Bufalino et. al. 2015).

The panel's capacity of absorption and desorption of moisture from wood polysaccharides when exposed to relative humidity causes changes in its volume. Cellulose and hemicellulose absorb water through hydrophilic sites which connect with water through hydrogen bonds. The hemicelluloses are more thermally unstable and reducing these polysaccharides in wood may increase their dimensional stability (Kok and Ozgur 2017, Korosec et al. 2017).

The search for alternatives to improve the dimensional stability of reconstituted wood products is mainly based on pre- and postproduction heat treatment (Del-Menezzi and Tomaselli 2006, Mendes et al. 2013b, Carvalho et al. 2015, 2018).

Pre-hydrolysis is a hydrothermal process with liquid heated water under pressure, used to hydrolyse hemicelluloses, which are easier to hydrolyse then cellulose, with a selective removal of these structures (Ruiz et. al. 2013). Acetyl groups and uronic acids resulting from hydrolysis, originally present in the hemicelluloses, catalyse the hydrolysis of those hemicelluloses (Yu et al. 2010). Hydrothermal pre-treatment in pulping process has been studied with a variety of raw materials, such as Pinus, Eucalyptus, sugarcane bagasse and Leucaena (Chirat et al. 2012, Feria et al. 2012, Saukkonen et al. 2012, Andrade and Colodette 2014). However, there are few studies using this treatment in the production of wood panels.

The hydrothermal process of pre-hydrolysis has potential for improving OSB dimensional 
stability. Therefore, the objective of this study was to evaluate the hydrothermal treatment of Eucalyptus strand particles and their effects on OSB's physical and mechanical properties.

\section{MATERIALS AND METHODS}

\section{Particle extraction and hydrothermal treatment}

Three Eucalyptus trees were harvested and their logs were sawn to obtain particles which were subjected to hydrothermal treatment. Logs were sawn into $9 \mathrm{~cm}$ lengths with wood grain, and $2.3 \mathrm{~cm}$ thickness. These pieces were submerged in water until complete saturation and processed in a wood chipper with blades adjusted to generate thickness of around $0.30 \mathrm{~mm}$ to obtain particle strands of $90 \mathrm{~mm}$ length $\times 23 \mathrm{~mm}$ width $\times 0.30 \mathrm{~mm}$ to thickness.

The particles were subjected to air-drying until they reached equilibrium moisture content. Then, they were subjected to hydrothermal treatment at 130,150 and $170{ }^{\circ} \mathrm{C}$ with 0.228 , 0.448 and $0.862 \mathrm{MPa}$ pressure, respectively, in a Parr reactor with an $18.75 \mathrm{~L}$ capacity and a waterwood ratio of $8: 1.5$. The heating rate was $1.71^{\circ} \mathrm{C}$ $\mathrm{min}^{-1}$ for seven and twenty-one minutes.

The pre-hydrolysed particles were washed in running water to remove potential extractives on their surface, and then dried at $25{ }^{\circ} \mathrm{C}$ until equilibrium of moisture content. The prehydrolysis yield was determined by equation 1 :

$$
\operatorname{ML}(\%)=\left(\frac{(\mathrm{Mi}-\mathrm{Mf})}{\mathrm{Mi}}\right) * 100
$$

where ML (\%) is the weight loss, and Mi and Mf are the mass of particles before and after the hydrothermal treatment, respectively.

Wood particles were conditioned in a climatic chamber at $20 \pm 2{ }^{\circ} \mathrm{C}$ and relative humidity of $65 \pm 3 \%$ until constant mass to determine the equilibrium moisture content, as shown in equation 2:

$$
\operatorname{EMC}(\%)=\left(\frac{(\mathrm{Mw}-\mathrm{Md})}{\mathrm{Md}}\right) * 100
$$

where EMC (\%) is the equilibrium moisture content of the samples, and $\mathrm{Mw}$ and $\mathrm{Md}$ are the wet and oven-dried particle mass, respectively.

\section{Wood chemical composition}

Wood particles were transformed into sawdust in a laboratory mill. The portion which passed through a 40-mesh sieve but retained by a 60 -mesh sieve was used. The total extractives content, carbohydrate content and the soluble and insoluble lignin contents were determined as per Kymalainen et al. (2017), with adaptations.

\section{Contact angle, $\mathrm{pH}$ and wood buffer capacity}

The contact angle of the phenol-formaldehyde resin with hydrothermally treated particle surface was obtained after adding $5 \mu \mathrm{L}$ phenolformaldehyde resin to the particles. The reading was carried out five seconds after mixing the resin and the wood particles, using a goniometer connected to a digital camera and a computer.

The $\mathrm{pH}$ was determined using the same sample as in the chemical characterisation. A total of $15 \mathrm{~g}$ of dry sawdust from each treatment and $150 \mathrm{~mL}$ distilled water at $100{ }^{\circ} \mathrm{C}$ were added into a beaker. This mixture was maintained for 30 minutes while stirring. Then the mixture was filtered in a funnel (porosity 2), and a $50 \mathrm{~mL}$ aliquot with the resulting liquid was analysed in a digital $\mathrm{pH}$ meter.

The buffer capacity was obtained by measuring the $\mathrm{pH}$ of the pure extract and the subsequent addition of sodium hydroxide solution $(\mathrm{NaOH})$ at 0.025 molar concentration. This alkaline solution was added until the sawdust solution reached $\mathrm{pH} 7$. The buffer capacity in $\mathrm{mmol} \mathrm{L}^{-1}$ was calculated according to the alkali quantity used.

\section{Panel production and characterisation}

Strand particles were dried in an oven with forced air circulation until the moisture level reached $3 \%$ (dry matter basis of the particles). The OSB panels with a nominal density of $0.70 \mathrm{~g} \mathrm{~cm}^{-3}$ were produced for each treatment. Phenolformaldehyde resin was used with viscosity $943 \mathrm{cP}$, solids content of $53.4 \%$, gel time at $170{ }^{\circ} \mathrm{C}$ of $64.3 \mathrm{~s}$ and $\mathrm{pH} 10.7$. A total of $8 \%$ resin of particle mass (dry basis) was sprayed using a rotary drum-type glue blender. After resin spraying, particles were placed in a $40 \times 40 \times$ $1 \mathrm{~cm}$ forming box to perform strand orientation in three layers $(25 \%+50 \%+25 \%$ of particles 
total mass). Subsequently, the panel was pressed at $170{ }^{\circ} \mathrm{C}$ for eight minutes at pressure $3.14 \mathrm{MPa}$. Then, the OSB panels were conditioned to $65 \%$ relative humidity at $23{ }^{\circ} \mathrm{C}$ until constant mass. Two centimeters were cut from each side to avoid edge effects.

Density, moisture (dry basis), thickness swelling and internal bond was determined according to the European committee for standardisation (EN 323 1993, EN 322 1993, EN 3171993 and EN 319 1993) standards respectively, while water absorption, modulus of elasticity and modulus of rupture in static bending were according to EN 3102006 standard. The results were compared with the requirements of the EN 3002006 standard.

\section{Data statistical analysis}

Data were submitted to the Lilliefors test for normality, and to the Cochran test for homogeneity of variances. The experiment was analysed according to a completely randomised design. Data were subjected to variance analysis by $\mathrm{F}$ test, and the means were compared using Scott-Knott test at 5\% significance level.

\section{RESULTS}

The content of extractives and insoluble, soluble and total lignin, as well as polysaccharides of both the control (untreated wood chips) and the treated particles are presented in Table 1.
The hydrothermal treatment at $130{ }^{\circ} \mathrm{C}$ reduced the extractives in wood particles, but increased at $150{ }^{\circ} \mathrm{C}$ and reached the highest values at $170{ }^{\circ} \mathrm{C}$. The insoluble lignin content remained constant, while the soluble lignin decreased with the treatment. Total lignin content remained unaltered by hydrothermal treatment.

Among the treatments, the galactan and xylan levels were lowered with hydrothermal treatment above $130{ }^{\circ} \mathrm{C}$. The arabinans, galactans and xylans showed their lowest values at $170{ }^{\circ} \mathrm{C}$, and the arabinans had similar values in treatments at 150 and $170{ }^{\circ} \mathrm{C}$. Eucalyptus wood contains mannans (Gírio et al. 2010), but the equipment did not detect this sugar. The $170{ }^{\circ} \mathrm{C}$ treatment for 21 minutes caused a decrease of $28.9,62.1$ and $62.2 \%$ in arabinan, galactan and xylan contents in the particles, respectively, compared to control.

The average values of equilibrium moisture content (EMC), mass loss, bulk density, $\mathrm{pH}$ variation of Eucalyptus particles and buffering capacity are shown in Table 2.

Heating the wood particles to $170^{\circ} \mathrm{C}$ for seven and twenty-one minutes reduced the EMC in the particles by 25.8 and $26.6 \%$, respectively, while heating to $150{ }^{\circ} \mathrm{C}$ reduced it by 10.2 and $18.8 \%$, respectively. The treatment at $130{ }^{\circ} \mathrm{C}$ did not affect the particle EMC. The sugar degradation of hemicelluloses (Table 1) reduced the particle hygroscopicity due to the availability of hydroxyl groups to make hydrogen bonds with water molecules.

Table 1 Chemical composition of Eucalyptus particles as a function of temperature and exposure time to hydrothermal treatments

\begin{tabular}{lccccccc}
\hline \multicolumn{1}{c}{$\%$} & Control & $\mathrm{T} 1$ & $\mathrm{~T} 2$ & $\mathrm{~T} 3$ & $\mathrm{~T} 4$ & $\mathrm{~T} 5$ & $\mathrm{~T} 6$ \\
\hline Total extractives & $2.22^{\mathrm{b}}$ & $1.61^{\mathrm{a}}$ & $1.77^{\mathrm{a}}$ & $4.38^{\mathrm{d}}$ & $3.13^{\mathrm{c}}$ & $8.97^{\mathrm{e}}$ & $8.77^{\mathrm{e}}$ \\
Insoluble lignin & $27.73^{\mathrm{a}}$ & $27.83^{\mathrm{a}}$ & $27.27^{\mathrm{a}}$ & $26.93^{\mathrm{a}}$ & $26.66^{\mathrm{a}}$ & $28.49^{\mathrm{a}}$ & $27.90^{\mathrm{a}}$ \\
Soluble lignin & $2.17^{\mathrm{c}}$ & $1.97^{\mathrm{c}}$ & $1.98^{\mathrm{c}}$ & $1.68^{\mathrm{c}}$ & $1.90^{\mathrm{c}}$ & $1.25^{\mathrm{b}}$ & $1.08^{\mathrm{a}}$ \\
Total lignin & $29.9^{\mathrm{a}}$ & $29.8^{\mathrm{a}}$ & $29.25^{\mathrm{a}}$ & $28.61^{\mathrm{a}}$ & $28.56^{\mathrm{a}}$ & $29.74^{\mathrm{a}}$ & $28.98^{\mathrm{a}}$ \\
Arabinans & $0.38^{\mathrm{a}}$ & $0.34^{\mathrm{a}}$ & $0.34^{\mathrm{a}}$ & $0.22^{\mathrm{b}}$ & $0.23^{\mathrm{b}}$ & $0.24^{\mathrm{b}}$ & $0.27^{\mathrm{b}}$ \\
Galactans & $0.66^{\mathrm{a}}$ & $0.54^{\mathrm{c}}$ & $0.66^{\mathrm{a}}$ & $0.60^{\mathrm{b}}$ & $0.59^{\mathrm{b}}$ & $0.33^{\mathrm{d}}$ & $0.25^{\mathrm{e}}$ \\
Glucans & $43.64^{\mathrm{d}}$ & $42.45^{\mathrm{e}}$ & $42.23^{\mathrm{e}}$ & $44.24^{\mathrm{d}}$ & $46.10^{\mathrm{c}}$ & $52.11^{\mathrm{b}}$ & $55.82^{\mathrm{a}}$ \\
Xylans & $14.48^{\mathrm{a}}$ & $13.12^{\mathrm{b}}$ & $12.70^{\mathrm{b}}$ & $11.73^{\mathrm{c}}$ & $12.92^{\mathrm{b}}$ & $7.01^{\mathrm{d}}$ & $5.47^{\mathrm{e}}$ \\
Mannans & $\mathrm{ND}$ & $\mathrm{ND}$ & $\mathrm{ND}$ & $\mathrm{ND}$ & $\mathrm{ND}$ & $\mathrm{ND}^{2}$ & $\mathrm{ND}$ \\
\hline
\end{tabular}

Means followed by the same letters per row do not differ at $95 \%$ probability level by Scott Knott test; $\mathrm{T} 1=130{ }^{\circ} \mathrm{C}$ $7 \mathrm{~min}, \mathrm{~T} 2=130{ }^{\circ} \mathrm{C}-21 \mathrm{~min}, \mathrm{~T} 3=150{ }^{\circ} \mathrm{C}-7 \mathrm{~min}, \mathrm{~T} 4=150{ }^{\circ} \mathrm{C}-21 \mathrm{~min}, \mathrm{~T} 5=170{ }^{\circ} \mathrm{C}-7 \mathrm{~min}, \mathrm{~T} 6=170{ }^{\circ} \mathrm{C}-21 \mathrm{~min}$ 
Table 2 Weight loss, equilibrium moisture content, $\mathrm{pH}$, buffer capacity and contact angle of pine particles as a function of temperature and exposure time to hydrothermal treatment

\begin{tabular}{cccccc}
\hline Treatments & Weight loss $(\%)$ & EMC $(\%)$ & $\mathrm{pH}$ & Buffer capacity $\left(\mathrm{mmol} \mathrm{L}^{-1}\right)$ & Contact angle \\
\hline Control & - & $12.8^{\mathrm{a}}$ & $4.53^{\mathrm{a}}$ & $0.0680^{\mathrm{a}}$ & $120.7^{\mathrm{a}}$ \\
$130^{\circ} \mathrm{C}-07 \mathrm{~min}$ & $3.7^{\mathrm{a}}$ & $11.9^{\mathrm{a}}$ & $4.08^{\mathrm{b}}$ & $0.0693^{\mathrm{a}}$ & $126.9^{\mathrm{b}}$ \\
$130^{\circ} \mathrm{C}-21 \mathrm{~min}$ & $4.5^{\mathrm{a}}$ & $12.0^{\mathrm{a}}$ & $4.07^{\mathrm{b}}$ & $0.0717^{\mathrm{a}}$ & $130.4^{\mathrm{c}}$ \\
$150^{\circ} \mathrm{C}-07 \mathrm{~min}$ & $6.3^{\mathrm{b}}$ & $11.5^{\mathrm{b}}$ & $3.39^{\mathrm{c}}$ & $0.1361^{\mathrm{b}}$ & $132.2^{\mathrm{c}}$ \\
$150^{\circ} \mathrm{C}-21 \mathrm{~min}$ & $7.9^{\mathrm{b}}$ & $10.4^{\mathrm{b}}$ & $3.37^{\mathrm{c}}$ & $0.1434^{\mathrm{b}}$ & $127.4^{\mathrm{b}}$ \\
$170^{\circ} \mathrm{C}-07 \mathrm{~min}$ & $13.5^{\mathrm{c}}$ & $9.5^{\mathrm{c}}$ & $3.09^{\mathrm{d}}$ & $0.2503^{\mathrm{c}}$ & $118.7^{\mathrm{a}}$ \\
$170^{\circ} \mathrm{C}-21 \mathrm{~min}$ & $16.3^{\mathrm{c}}$ & $9.2^{\mathrm{c}}$ & $3.08^{\mathrm{d}}$ & $0.2420^{\mathrm{c}}$ & $115.7^{\mathrm{a}}$ \\
\hline
\end{tabular}

Means followed by the same letters do not differ at 95\% probability level by Scott Knott test; EMC = equilibrium moisture content

The mass loss was highest at $170{ }^{\circ} \mathrm{C}$, and the degradation of wood constituents, mainly hemicelluloses, was greater at higher temperatures which resulted in greater wood mass losses.

The Eucalyptus wood $\mathrm{pH}$ was 4.53 , which decreased with hydrothermal treatment as the temperature increased. The treatment period per temperature did not affect the $\mathrm{pH}$ values.

The hydrothermal treatment at temperatures 130 and $150{ }^{\circ} \mathrm{C}$ increased the contact angle between Eucalyptus particle surfaces and phenol formaldehyde adhesive, in relation to the control. The wetting properties of the adhesive on particle surface decreased due to lower surface area at the given volume. The treatment at $170{ }^{\circ} \mathrm{C}$ did not influence the adhesive wettability of the particles.

\section{Characterisation of oriented stand board (OSB) panels}

\section{Physical properties of OSB panels}

The average values of density, EMC, water absorption (WA) and thickness swelling (TS), after 24 hours of immersion of the OSB in water, are shown in Figure 1

The panels produced with particles treated at $170{ }^{\circ} \mathrm{C}$ were included in the category of highdensity panels (over $0.80 \mathrm{~g} \mathrm{~cm}^{-3}$ ), while the others were classified as medium-density panels, with values between 0.64 and $0.80 \mathrm{~g} \mathrm{~cm}^{-3}$ (American National Standard 1993).

The $170{ }^{\circ} \mathrm{C}$ temperature decreased EMC by $18.9 \%$ (seven minutes) and $18.2 \%$ (21 minutes) compared to control panel. The water absorption values were lowered for panels produced with particles treated at $170{ }^{\circ} \mathrm{C}$ (Figure 1). The TS24h panels, containing particles treated hydrothermally at $170{ }^{\circ} \mathrm{C}$ for 21 minutes was lowest, while the $130{ }^{\circ} \mathrm{C}$ treatment for 21 minutes, and the $150{ }^{\circ} \mathrm{C}$ treatment for seven minutes increased TS24h.

\section{Mechanical properties of oriented strand board $(O S B)$}

Average values of mechanical properties, modules of rupture and bending elasticity of OSB are presented in Figure 2.

The panels treated at 150 and $170{ }^{\circ} \mathrm{C}$ for 21 minutes had the highest density and modulus of elasticity in perpendicular directions $(\mathrm{MOE} / /)$.

The modulus of elasticity in parallel directions $(\mathrm{MOE} \perp)$ and modulus of rupture in perpendicular directions $(\mathrm{MOR} / /$ ) were not affected by the treatments, and their values in all the treatments were the same as control (untreated wood chips). The panels produced with wood particles hydrothermally treated at $150{ }^{\circ} \mathrm{C}$ for seven minutes showed lower values of modulus of rupture in parallel directions $(\mathrm{MOR} \perp)$ than control. The MOE and MOR static bending did not show a tendency to increase or decrease with the treatment intensity.

There was no appreciable effect of hydrothermal treatment on the internal bond of the panels. Control had $0.47 \mathrm{MPa}$, while the treatments were $0.42 \mathrm{MPa}$ $\left(130{ }^{\circ} \mathrm{C} / 7 \mathrm{~min}\right), 0.39 \mathrm{MPa}\left(130{ }^{\circ} \mathrm{C} / 21 \mathrm{~min}\right)$, $0.38 \mathrm{MPa}\left(150{ }^{\circ} \mathrm{C} / 7 \mathrm{~min}\right), 0.40 \mathrm{MPa}\left(150{ }^{\circ} \mathrm{C} /\right.$ $21 \mathrm{~min}), 0.52 \mathrm{MPa}\left(170^{\circ} \mathrm{C} / 7 \mathrm{~min}\right)$ and $0.43 \mathrm{MPa}$ $\left(170{ }^{\circ} \mathrm{C} / 21 \mathrm{~min}\right)$. 

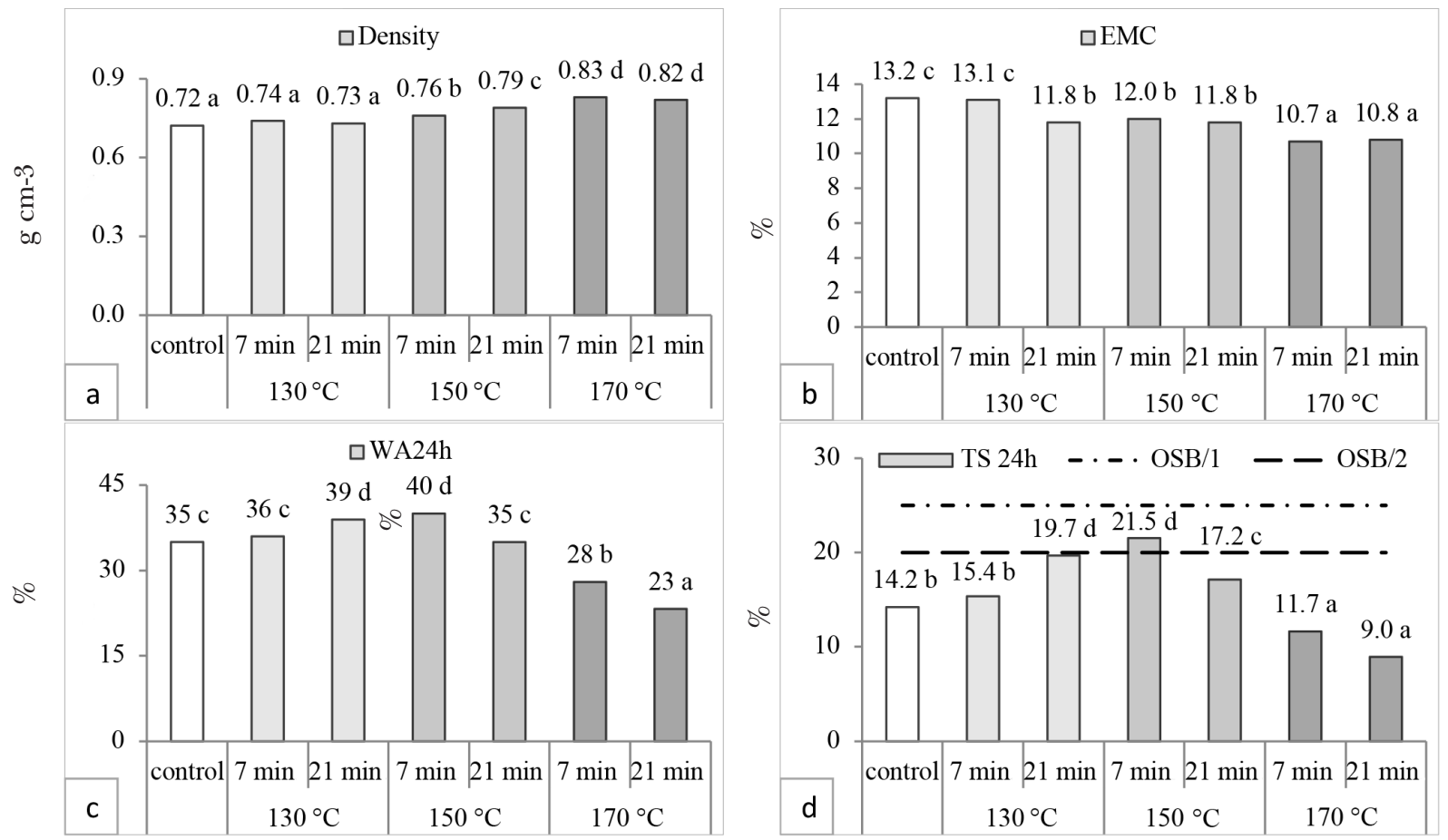

Figure 1 Apparent density (a), equilibrium moisture content (b), water absorption (c), and thickness swelling (d) after 24-hour immersion of the OSB panels following hydrothermal treatment; means followed by the same letters in the column do not differ at $95 \%$ probability level by the Scott Knott test; EMC = equilibrium moisture content, WA = water absorption, TS = thickness swelling
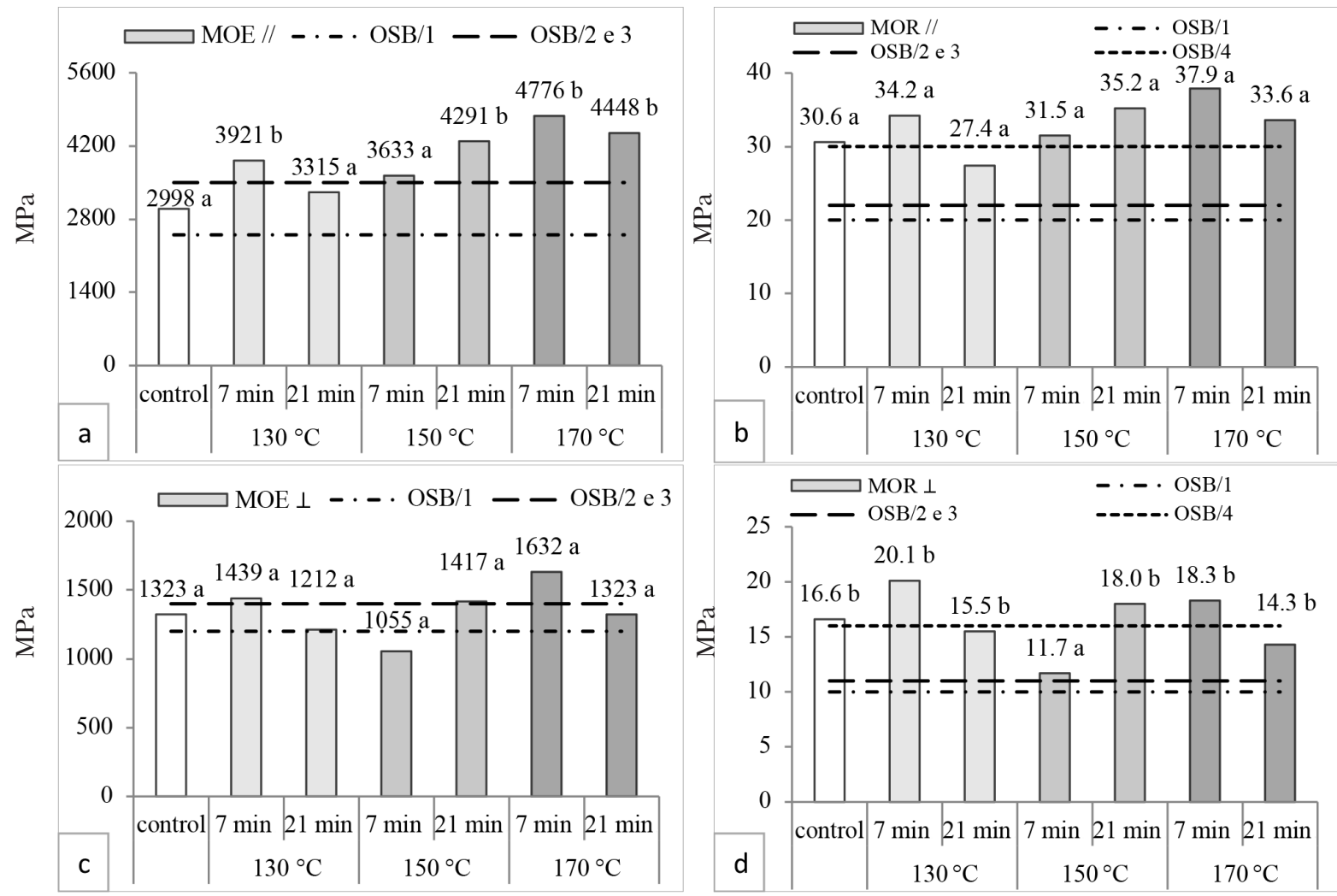

Figure 2 Parallel elasticity modulus (a), parallel rupture modulus (b), perpendicular elasticity modulus (c) and perpendicular rupture modulus $(\mathrm{d})$ as functions of temperature and period of hydrothermal treatment; means followed by the same letters in the column do not differ at $95 \%$ probability level by Scott Knott test 


\section{DISCUSSION}

The increase in extractive content in hydrothermal treatmenst of 150 and $170{ }^{\circ} \mathrm{C}$ (Table 1) is due to degradation of hemicelluloses (Brito et al. 2008; Esteves and Pereira 2009). Hemicelluloses are polysaccharides which are thermally unstable, and when submitted to thermal treatment, they are degraded (Esteves et al. 2013). Once submitted to hydrothermal processing, hemicellulose depolymerisation occurs, forming soluble compounds such as oligosaccharides, monosaccharides, sugardecomposition products and acetic acid (Gullón et al. 2010). Zanuncio et al. (2014) also reported the increase of extractive content in heat-treated Eucalyptus grandis wood at 200 and $230{ }^{\circ} \mathrm{C}$.

Reduction in the sugars composing the hemicellulose structure (Table 2) can be explained by the fact that hemicelluloses are less tolerant to heat because their ramifications are easily removed from the main chain, degrading into volatile compounds (Wang et. al. 2017). The glucan content, as a component of cellulose, has greater thermal stability compared to other carbohydrates (He et al. 2019), increasing its percentage when treated at 150 and $170{ }^{\circ} \mathrm{C}$ for 21 minutes (Table 1 ).

Altering the treatment period at the same temperature did not affect mass losses or EMC, but altering the temperature affected mass loss and reduced EMC, with major differences occurring in the particles between treatments at 150 and $170{ }^{\circ} \mathrm{C}$ (Table 2).

The $\mathrm{pH}$ reduction was attributed to the formation of carbonic acid, acetic acid (mainly because of deacetylation during the hydrolysis of polyose), and acetyl groups (Tjeerdsma and Militz 2005, Gullón et al. 2010).

The wood buffering capacity showed its ability to resist $\mathrm{pH}$ changes in the environment. The temperatures of 150 and $170{ }^{\circ} \mathrm{C}$ increased the wood chip buffering capacity. Phenol formaldehyde adhesives cure faster in alkaline $\mathrm{pH}$, increasing the buffering capacity of the particles in acidic $\mathrm{pH}$, influencing the adhesive curing speed and decreasing the curing time.

The contact angle did not show a sequential increase as a function of increasing temperature, with higher contact angles at higher temperatures. The contact angle of heat-treated Eucalyptus cloeziana wood in distilled water showed an increase, confirming that wood heat treatment reduces its hygroscopicity (Cardematori et al. 2013). The authors also did not observe a sequence of increasing contact angles as a function of increasing temperature, with higher contact angles at temperatures of 180 and $200{ }^{\circ} \mathrm{C}$ than at 220 and $240{ }^{\circ} \mathrm{C}$.

\section{Characterisation of panels}

\section{Physical properties of oriented stand board (OSB) panels}

The density of the panels produced with particles treated at 150 and $170{ }^{\circ} \mathrm{C}$ was higher than control and those treated at $130{ }^{\circ} \mathrm{C}$.

Lower thickness leads to lower panel volume, and the panel density is determined by the ratio between mass and volume. Thus, it is possible to infer that the increased density of panels produced with pre-hydrolysed particles was mainly based on their lesser thickness.

In another study, a reduction in the thickness of the panels was observed in OSB heat-treated at $250{ }^{\circ} \mathrm{C}$ for 4.7 and 10 minutes, but mass losses of the panel corresponding to increase in density was not observed (Del-Menezzi and Tomaselli 2006). The lack of effect of mass loss on panel density was due to the application of hydrothermal treatment to particles before constructing the panel. This explains the increase in density of the panels after hydrothermal treatment, and a decrease in the panel thickness.

The panel EMC followed the same trend as the strands, with temperature of $170{ }^{\circ} \mathrm{C}$ being the most efficient for reducing this parameter. The water absorption values were lower for the panels produced with particles treated at $170{ }^{\circ} \mathrm{C}$ (Figure 1).

The hydrothermal treatment at temperature $170{ }^{\circ} \mathrm{C}$ was the most efficient for improving dimensional stability of OSB. However, the WA24h and TS24h (water absorption and thickness swelling after $24 \mathrm{~h}$ of OSB immersion in water) did not show a tendency to increase with treatment temperature or time. In a similar fashion, thermally treated strand particles of pine at 200 and $240{ }^{\circ} \mathrm{C}$ did not display a direct corelation between treatment temperature and OSB dimensional stability, with an increase in thickness swelling values at $200{ }^{\circ} \mathrm{C}$ and a reduction at $240{ }^{\circ} \mathrm{C}$ (Mendes et al. 2013b). 
The results were related because hydrothermal treatment degraded the hemicelluloses (Table 1) and hydrophilic sites of the particles, resulting in lower panel EMC, WA and TS.

The panels containing particles treated at $170{ }^{\circ} \mathrm{C}$ for seven minutes reached minimum TS value stipulated for OSB type 4 (TS24h $<12 \%)$. The chips treated at $170{ }^{\circ} \mathrm{C}$ for both seven and twenty-one minutes, as well as control, met the minimum TS value required for OSB type 3 $(\mathrm{TS} 24 \mathrm{~h}<15 \%)$. However the particles treated at $150{ }^{\circ} \mathrm{C}$ for seven minutes did not meet the minimum TS value for OSB type 2 (TS24h < $20 \%$ ). All panels attended the minimum TS value stipulated by the relevant standard for OSB type 1 (TS24h < 25\%) (EN 300 2006).

\section{Mechanical properties of oriented stand board $(O S B)$}

All treatments attended the minimum value stipulated for MOE// by the European norm EN 300 (2006) for OSB type 1, with a minimum of $2500 \mathrm{MPa}$ for this property. The panels produced with particles treated at 130, 150 and $170{ }^{\circ} \mathrm{C}$ for seven minutes also met the standard $\mathrm{MOE} / /$ requirement for OSB type 2 and 3, with a minimum of $3500 \mathrm{MPa}$.

All panels attendeded the minimum value stipulated for MOR// by EN 300 (2006) for OSB types 1,2 and 3 , where the requirement is 20,22 and $22 \mathrm{MPa}$, respectively. The panels containing particles treated at $130^{\circ} \mathrm{C}$ for 21 minutes did not meet the standard for OSB type 4, which requires at least $30 \mathrm{MPa}$.

Panels produced with particles treated at $150{ }^{\circ} \mathrm{C}$ for seven minutes also did not meet the requirements for $\mathrm{MOE} \perp$ of the European standard for OSB type 1 (EN300 2006), a minimum of $1200 \mathrm{MPa}$. The panels containing particles treated at $130{ }^{\circ} \mathrm{C}$ for seven minutes, $170{ }^{\circ} \mathrm{C}$ for seven minutes and $150{ }^{\circ} \mathrm{C}$ for 21 minutes met the minimum $\mathrm{MOE} \perp$ values for $\mathrm{OSB}$ panels type 2 and 3 (1400 MPa).

All panels attend the European standard requirements for OSB type 1, 2 and 3 (EN300 2006) for MOR $\perp$. The control OSB panels and those with particles treated at $130{ }^{\circ} \mathrm{C}$ for seven minutes, $170{ }^{\circ} \mathrm{C}$ for seven minutes and $150{ }^{\circ} \mathrm{C}$ for 21 minutes reached the minimum value stipulated for type 4 OSB panels.

All panels met the minimum value established for internal bonding by the EN 300 (2006) standard for type 1, 2 and 3 OSB panels, with values higher than $0.3,0.34$ and $0.34 \mathrm{MPa}$, respectively.

\section{CONCLUSIONS}

Hydrothermal treatment altered the chemical composition of wood particles. The increase in temperature, mainly at $170{ }^{\circ} \mathrm{C}$, degraded the hemicelluloses, reducing the galactan, xylan and arabinan contents, resulting in a loss of particle density. The degradation of these components reduced the wood's adsorption capacity and, therefore, the OSB panels submitted to the hydrothermal treatment had lower equilibrium moisture content and swelling. In addition, panels treated at higher temperatures maintained their mechanical resistance, due to their higher densities, which contributed to this resistance.

\section{REFERENCES}

American National Standard. 1993. Mat Formed Wood Particleboard: Specification ANSI/A 208.1.1993. National Particleboards Association, Gaithersburg.

Andrade MF \& Colodette JL. 2014. Dissolving pulp production from sugar cane bagasse. Industrial Crops and Products 52: 58-64.

Brito JO, Silva FG, Leão MM \& Almeida G. 2008. Chemical composition changes in Eucalyptus and Pinus woods submitted to heat treatment. Bioresource Technology 99: 8545-8548.

Bufalino L, Côrrea AAR, De Sá VA, Mendes LM, Almeida NA \& Pizzol VD. 2015. Alternative compositions of oriented strand boards (OSB) made with commercial woods produced in Brazil. Maderas. Ciencia y tecnología 17: 105-116.

Cardematori PHG, Santos PSB, Serrano L, Labidi J \& Gatto DA. 2013. Effect of thermal treatment on physicochemical properties of Gympie messmate wood. Industrial Crops and Products 45: 360-366.

Carvalho AG, Mendes RF, Oliveira SL \& Mendes L. 2015. Effect of post-production heat treatment on particleboard from sugarcane bagasse. Materials Research 18: 78-84.

Carvalho AG, Zanuncio AJV, Vital BR, Carneiro ACO \& Silva CMS, Tonoli GHD. 2018. Hydrothermal treatment of strand particles of pine for the improvement of OSB panels. European Journal of Wood and Wood Products 76: 155-162.

Chirat C, Lachenal D \& Sanglard M. 2012. Extraction of xylans from hardwood chips prior to kraft cooking. Process Biochemistry 47: 381-385.

Del-menezzi CHS \& Tomazelli I. 2006. Contact thermal post-treatment of oriented strand board to improve dimensional stability: a preliminary study. European Journal of Wood and Wood Products 64: 212-217.

Delucis RA, Santos PSB, Beltrame R \& Gatto DA. 2009. Chemical and fuel properties of forestry wastes from pine plantations. Revista Árvore: 41: 1-7.

Esteves BM \& Pereira HM. 2009. Wood modification by heat treatment: A review. BioResources 4: 370-404. 
Esteves BM, Marques AV \& Pereira HM. 2013. Chemical changes of heat treated pine and eucalypt wood monitored by Ftir. Maderas. Ciencia y Tecnología 15: 245-258.

European Committee for Standardization. 2006. EN 300: Oriented Strand Boards (OSB) - Definitions, Classification and Specifications. European Committee for Standardization, Brussels.

European Committee for Standardization. 1993. EN 310: Wood-Based Panels - Determination of Modulus of Elasticity in Bending and of Bending Strength. European Committee for Standardization, Brussels.

European Committee for Standardization. 1993. EN 317. Particleboards and Fiberboards, Determination of Swelling in Thickness After Immersion. European Committee for Standardization, Brussels.

European Committee for Standardization. 1993. EN 319: Particleboards and Fibreboards - Determination of Tensile Strength Perpendicular to The Plane of The Board. European Committee for Standardization, Brussels.

European Committee for Standardization. 1993. EN 322: Wood-Based Panels - Determination of Moisture Content. European Committee for Standardization, Brussels.

European Committee for Standardization. 1993. EN 323: Wood-Based Panels - Determination of Density. European Committee for Standardization, Brussels.

Feria M, García J, DíaZ M, Fernández M \& López F. 2012. Biorefinery process for production of paper and oligomers from Leucaena leucocephala K360 with or without prior autohydrolysis. Bioresource Technology 126: 64-70.

Gírio FM, Fonseca C, Carvalheiro F, Duarte lC, Marques S \& Bogel-Łukasik R. 2010. Hemicelluloses for fuel ethanol: a review. Bioresource Technology 101: 4775-4800.

Gullón B, Yanez R, Alonso JL \& Parajó JC. 2010. Production of oligosaccharides and sugar from rye straw: a kinetic approach. Bioresource Technology 101: 66766684.

He Q, Ding L, Gong Y, Li W, Wei J \& Yu G. 2019. Effect of torrefaction on pinewood pyrolysis kinetics and thermal behavior using thermogravimetric analysis. Bioresource Technology 280: 104-111.

Kok MV \& Ozgur E. Characterization of lignocellulose biomass and model compounds by thermogravimetry. 2017. Energy Sources, Part A: Recovery, Utilization and Environmental Effects 39: 134-139.

Korosec RC, Renko S, Rep G \& Bukovec P. 2017. Determination of the thermal modification degree of beech wood using thermogravimetry. Journal of Thermal Analysis Calorimetry 130: 1383-1390.

Kymalainen M, Mlouka SB, Belt T et al. Chemical, water vapour sorption and ultrastructural analysis of Scots pine wood thermally modified in high pressure reactor under saturated steam. Journal of Materials Science 53: p. 3027-3037.

Mendes RFM, Bortoletto JRG, Garlet A, De Almeida NF \& SuRdi PG. 2013a. Resistência ao ataque de fungos apodrecedores em painéis OSB termicamente tratados. Cerne 19: 551-557.

Mendes RFM, Bortoletto JRG, De Almeida NF, Surdi PG \& BARBEIRo IN. 2013b. Effect of thermal treatment on properties of OSB panels. Wood Science Technology 47: 243-256.

Moslemi AA. 1974. Particleboard. Southern Illinóis University Press, Carbandale.

Ruiz HA, Rodríguez-Jasso RM, Fernandes BD, Vicente AA \& TeixeIra JA. 2013. Hydrothermal processing, as an alternative for upgrading agriculture residues and marine biomass according to the biorefinery concept: a review. Renewable and Sustainable Energy Reviews 21: 35-51.

SANChes FL, Hilling E, Iwakiri S \& NAPOLI LM. 2016. Strength of particleboard produced with mixed wood traditional and nontraditional forest species. Ciência Florestal 26: 559-569.

Saukkonen E, Kautto J, Rauvanto I \& Backfolk K. 2012. Characteristics of rehydrolysis-kraft pulp fibers from Scots pine. Holzforschung 66: 801-808.

TJeerdsma B \& Holger M. 2005. Chemical changes in hydrothermal treated wood: FTIR analysis of combined hydrothermal and dry-heated wood. European Journal of Wood and Wood Products 63: 102-111.

Yu G, Yano S, Inoue H, Inoue S, Endo T \& Sanayama S. 2010. Pretreatment of Rice Straw by a Hot-Compressed Water Process for Enzymatic Hydrolysis. Applied Biochemistry and Biotechnology 160: 539-551.

Wang H, Chen Y, Wei Y, Zhang A \& Liv C. 2017. Homogeneous esterification mechanism of bagasse modified with phthalic anhydride in ionic liquid. Part 2: reactive behavior of hemiceluloses. Carbohydrate Polymers 157: 1365-1373.

Zanuncio AJV, Nobre JRC, Motta JP \& Trugilho PF. 2014. Química e colorimetria da madeira de Eucalyptus grandis W. Mill ex Maiden termorretificada. Revista Arvore 38: 765-770. 